The first time I man across a portion of the blaclder in the hernial sale, I unfortunately opened it, but that is a mistake one practically never make's a second time. It will be interesting if I\%: Royster in closing will elaborate a little more fully upon the presence or absence of deformities elstwhere in the body.

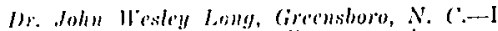
think it would be diflicult to diagnose such an wnustal condition. 1 hase scen only one case of the kind. This was thirty years ago and it occurred in an infant of about three and a half months, which hatd heen delivered at seren and a half months while the mother wats in the midst of triboial fever. A month or so after birth there was noticed a little lump in the left inguinal regron, which would appear and disappear. When the child was ahout three and a half months ald the lump became tixed. In other words, it was mildly stmangulated. (Bo opening the sale I was sulpprised to find the uterus, tubes and oraries. 'lhey were not adherent and were easily reduced. The incision wats closed in the usual manner with prompt healing. I tooked up the literature at the time and foumd that several similar tast's had been reported.

1r. Ilarres skimuer, Selma, .Hu.-Although a younir man. I have seen two tases of hernia of the uterlis in which the tube and vally were stringulated. One ease was in 1)r. Eidman's servipe in Now Jork and one was seren with Dr. Ilalper, of Solma. Both cases occurred in thilbren under six months of age and both were oprerated upon for high labial abscess. I)r. Erdmas, before operating, ventured the opinion that the condition might be one of labial absecess or it might be the tube and ovary in the inguinal canal, as he had seen the latter condition before. In both of these cases the strangulated tube and ovary were found in the camal, amputation wats lone at the uterine cornua and the patients recovered. I never expect to see another such citse.

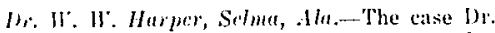
Skimmer referred to was a child four or five months of age, who was brought in as a possible labial abscess. The labia was very much swollen and the doctor who trought her in thought it might be a hernia. Under local anesthesia we operated and found a stringulated ovary, which we tied off and completed the operation for radical cure of the hernia. An hour afterward the balys was nursing and made an 111 . evintful recovery.

Ir. Royster (dosing)-Ahout the only re. marlis I have to make in closing are in connection with showing the pictures, heause I am afraid the photorraphs have not been understood. The patient I referred to had no other abnormalities. Even the varina was as normal as could be seen, exeept that there was no cer:vix. The pediele came acrosis from the broal ligament and there was no well-formed os or cervix.

\section{THE MANAGEMENT OF TUMORS OF THE URINARY BLADDER*}

BY Edgar G. Ballenger, M.D., F.A.C.S., Professor of Genito- Grinary Diseases. Iedical Department, Emory University, and.

OMAR F. ELder, H.D., Atlanta, Gai.

There are several notable landmarks in the development of the treatment of tumors of the blatder:

1. The invention of the cystoscope by Nitze and his endovesieal operations with snatres, torceps, etc:

2. The discovery by Beer of the favorable influence of the high frequency current upon papillomis;

:) The use of radium applied to bladder tumors by Barringer, Kelly, Geraghty, Foumer and other's; and

4. The development of the intensive and thorough use of the cantery through a supra-pubic incision with protective packings in the perivesical wound, as suggested by Feer. to lessen the danger of implanting new growths on the raw surfaces.

Through these developmental stages the improvement has been chiefly with papillomas, while little change for the better has resulted in the malignant tumor's except the malignant papillomas, which can be influenced farorably by the high frequency current, or destroyed by the cautery, the application of radium or complete excision.

In practical work with the new growths in the bladder there are three well recognized grouns, as follows: (1) benign papillomas; (2) malignant papillomas (which sometimes may look benign when viewed with the cystoscope, but which microscopically are malignant and may fail to respond to the high frequency current as do the benign growths) ; and (3) papillary careimonas and sarcomas which infiltrate the bladder wall.

We shall not diseuss carcinomas which extemd by direct contiguity from prostatic, rectal or uterine growths.

Rear in Section on Urology, Southern Medial Association. Thirteenth Annual Heeting, Asheville, X. C. Nov. 10.13, 1919 . 
Genito-urinary surgeons almost unanimously agree that for the benign neoplasms the high frequency current is the remedy of choice. Fortunately the maiority of tumors of the bladder come in this class.

There is also a fairly unanimous opinion that if the malignant papillomas fail to respond reasonably promptly to the high frequency current or to radium or both, they demand a radical operation, destruction with the actual cautery, excision, or cautery excision. Various factors determine the advisability and feasibility of the remedies, such as the age, physical condition of the patient and the location and size of the tumor or tumors. If the growth is undoubtedly nalignant or infiltrating, or if it is so situated that it will require transplantation of the ureters and perhaps total erstectomy, the plan to be followed is less dogmatic and depends also upon many factors, such as the age and vitality of the patient, the probability of successful removal of all the malignant growth, and fimally upon the wishes of the patient after the facts and probabilities are explained.

\section{BENIGN PAPILLOMAS}

Having thus given a brief summary of the three groups of vesical neoplasms, we shall now consider more in detail the benign growths. There is but one symptom which is present often enough to be of much value in the diagnosis, and that is hematuria. If there is no readily assignable cause for it, such as inflammatory processes, traumatism or tuberculosis of the genito-urinary tract, we think of a neoplasm, and, if the patient is in middle life, of a papilloma. The amount of blood in the urine may not be in proportion to the size of the papilloma. The most profuse hemorrhage we have seen from a bladder came from a benign papilloma not larger than a pea. The diagnosis of the neoplasm is confirmed when the growth is seen through a cystoscope. If the patient is under 35 , and if the neoplasm conforms to the type we recognize as papilloma, and if the base (if seen) is apparently not infiltrated, and if there are no nodules around its attachment to the bladder wall, and if there are no ulcerations or erosions on it, and if there is not a troublesome cystitis and no incrustations, the probability is that the neoplasm we see is a benign papilloma, provided the microscopic examination of the specimen obtained is negative when sectioned and studied for malignancy, and provided there is a promptly farorable response to the high frequency current. You may say there are too many "ifs" in this last sentence, but they are all important factors and we can not disregard them, as not infrequently we have to depend upon the total clinical picture rather than any single symptom or finding.

The medical profession, as well as the public, should be emphatically impressed with the importance of blood in the urine as a symptom which demands an examination to determine $\mathrm{jts}$ source and cause. Farly crstoscopic examinations would thus oreasionally save a patient's life by permitting the prompt employment of remedial measures which at il later perior would be useless. This is true of renal tuberculosis as well as neoplasns of the bladder. The majority of malignant papillomas are at first benign; the malignancy and infiltration are perhaps the price of delay or inappropriate truatment.

The eystoscopic examination of a tumor of the bladder is a very simple one, but the differentiation of a benign or malignant papilloma from the papillary carcinoma may at times be difficult or impossible. To distinguish the benign from the malignant papilloma is of less importance, for the final test is the response to the high frequency current. Small single neoplasms occurring in early life are usually benign, while large multiple ones after 40 are frequently malignant. The majority of tumors of the bladder, even if benign at first, if neglected indefinitely, become malignant.

Sarcoma is prone to occur in early life 'though sometimes as late as 40 or 50 years of age; it is more round, more regular and solid looking and has, usually, a smooth appearance. The malignancy of a neoplasm may be suspected from the fixation or thickening of its pedicle or the mucosa around its attachment; also from its vaseularity, edema, inelasticity and distortions, erosions, cystitis and incrustatians.

The majority of malignant papillomas, if treated early, yield to the high frequency current. We do not mean, how. 
ever, that time should be wasted until the period is passed when more radical meas. ures, such as destruction with the cautery or excision, might be employed with advantage or perhaps ladium given a trial.

\section{HISTOLOGICAL EXAMINATION}

The histologieal study of a section obtained from the growth may be either of definite value or may be entirely mislead. ing. Naturally much depends upon the size and character of the specimen. Where a reasonably large selected specimen is obtained by the snare, rongeur forreps, or some such instrument, something of value may be determined by its proper study by a competent pathologist. If, however, we rely upon a casual histological diagnosis made from a fringe of tissue, perhaps accidentally broken off, we are more likely to be misled by its study than we would be from the cystoscopic picture and the clinical history. If possible, the specimen taken for examination should be from a part showing necrotic changes, if such are present.

\section{RADIUM}

The exact status of radium is not definitely settled, but there are certain tumors which disappear under its use, as with the high frequency, while others are not favorably influenced by it.

Geraghty has found that there is a group of neoplasms which fail to respond to the high frequency until after they are treated with radium, but admits that if a longer time had been allowed to elapse, they might have disappeared from the radium treatment alone.

Young and Barringer have found radium of vajue in the treatment of malignant papillomas and in the control of papillary carcinomas which for varjous reasons are unenitable for cauterization partial or complete cystectomy.

\section{RECURRENCES}

As is well known, benign papillomas; show a great tendency to multiple recurrences. In fact, this was the chief reason why the high frequency treatment quickly replaced the older excision method which was frequently followed by recurrences, usually multiple and extensive. With the high frequency, the prognosis is vastly better in the benign papillomas than by excision; this statement also applies to ordi- naly recurrences but does not apply to those which are at first very extensive or those which are multiple recurences, papillomatosis. For these neoplasms it is better to employ the cautery through a supra-pubic incision with protective packings in the perivesical wound, as suggested by Heer. to prevent implantations upon the ma surtaces.

\section{MALIGNANT PAPILLOMAS}

When neoplasms of the papilloma type undergo malignant changes in the villi, but the process has not extended to the bladder wall, we designate it a malignant papilloma. These growths are at times difficult to differentiate from those which have infiltrated the bladder wall and which we call papillary carcinoma. As previutsly stated, malignant papillomas may respond promptly to the high frequency current, but if they fail to yield, they then demand the same serious attention and radical measures that are required for papillary carcinomas.

Any papilloma which shows necrotic changes should at once be considered malignant and if the indications are that the bladder wall is not involved, it should be placed in the group which requires especial attention. It may still respond to high frequency or radium, but if it does not, it should be destroyed or excised by the cautery or removed by partial or total cystectomy before inoperable extensions have developed. We may regard as undoubtedly malignant a tumor which has become eroded and incrusted and has infiltrated the bladder wall or shows multiple nodules or bulbous edema around its base. Still further evidence is the foulsmelling urine with a persistent cystitis in a patient over 30 or 40 years of age. Whenever we find such symptoms, we may assume that the neoplasm is malignant and sufliciently long standing and extensive to recuire radical measures. These will depend upon many factors such as the age, vitality and temperament and inclination of the patient and upon the size, number and location of the neoplasms.

Bi-namual palpation through the rectum or the ragina in women should be done to determine if the neoplasm is palpable and to ascertain if it is secondary to a growth of the prostate gland, the seminal vesicles, rectum or uterus. 


\section{HIGH FREQUENCY TREATMENT}

The high frequency current is applied to the papilloma through an insulated electrode, using an operating or catheterizing cystoscope. Beer prefer's the monopolar current. In our work, the bipolar current has given results that have been just as good as the monopolar and it is more satisfactory to employ.

Where possible the current is applied near the pedicle. It is allowed to flow for about 30 seconds or until the area treated has turned white. The electrode is then placed on another place until all of part of the growth is destroyed. A rystoscopic examination is made atter a week has elapsed and the treatment repeated if any of the growth remains. Subsequent examinatinns are made about nnce a month to be sule there is no recurrence and to treat it prompty if there is.

\section{RADIUM APPIACATIONS}

We have had no personal experience with the applications of radium. The technic employed varies with different operators. Rarringel applies it through a crstoscope and leaves the small tube in 'the bladder, having the patient assume and nuantain a position which will cause the radium to come near the tumor. Geraghty applies it through the cystoscope, which is held in position by means of clamps.

\section{CAUTERY TREATMENT}

The plan suggested by Beer of cauterizing the tumors of the bladder through a suprapubic incision, taking the utmost care to prevent implantations, is probably the most satisfactory technic.

The only change we make in his technic is to distend the bladder until the peritoneum is stripped well back and the vesical wall is separated from the surrounding tissue. The distending fluid is then drawn off through the catheter before the bladder is opened. Beer works without the bladder distention, using the urachus tor traction.

Cauterization is greatly facilitated by the use of a good bladder speculum with a light, and a tube leading to the bottom of the bladder to draw away the smoke, urine and blood by means of a suction device surh as is used in tonsil operations.

The perivesical tissues are thoroughly protected through the entire operation with alcohol sponges to prevent implantations.

Time forbids discussion of any of the above methods in detail or of going inta any of the operative measures required for ureteral implantation, cystectomy, etc. $80 \overline{5}$ Hedely Bldly.

\section{1)ISCUSSION}

J). Joln R. Comlk, St. Lowis, Mo.-As urola. rists I think our thiei nission is to impress the prists I thioners with the fact that in these blader

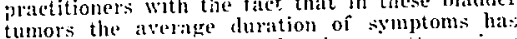
tumors ten yeas. 1 think that is a pretty seriou: problem, due to the fact that the initial symptoms are so insidious. They fool the patient and the doctal'. 'That we must teach the greneral the doctor. 'That we must the tumors of the practider, many of the malignant and all of the Imoign can be trated with the high frequeney cuerent. If yeu have an alternating culvent you seldon have any trouble, but if you have to transform the curvent there is ajt to be short circuiting and back firing. If you isolate the table on good henvy glass eastei's they will obviate the difficulty. The rreat difficulty is in the treatment of the infiltrated papilloma and epithelioma of the bladder. My results in the tratment of bladder cancer have heen very poor, beasuse of the fact that the patients came so liate. They have usually been present for ten to fifteen years and have involved the whole neck of the bladider before the patients present themselves. In a whole series of seventy-five or eighty eases there have been only six that were definitely dissectable. The others have been treated palliatively by cauterization. I have nover done a complete eystectomy and have never felt that it was justifiable. We have been freeing the bladder so that we could watch our manipulations, and I feel that it is very important to have the bladder completely free throughout before attempting resection. I often put in a ureteral catheter on the side corresponding to the tumor to protect the ureter After dissecting the tumor in this way we have placed the catheters in the ureters and kept the bladder nice and dry, and we get a dry union and prompt healing. In six cuses we have had rery good results; three are three years, two are two years old, and one is about a year old. About a moith ago one patient came back with a small recurrence in the site of the scar and two high frequency treatments healed it up.

1 think the main thing we have to do is to let the profession know the seriousness of the insidious symptoms and the hematuria.

Dr. G. Timberlalic, Bultimore, Wd.-We seldom take seriously enough subjectively symptomless hematurias. This condition as a symptom is none other than a cali for investigation, apprehension of source and cause. There are so many points betwixt the meatus urinarius and the upper kidney poles which require careful inspection that we should take into account the mirutest details. 
While the clinical picture and character of hlood, along with its disposition from the bladder. lead to possible diugnosis, without doubt, for complete diagnosis, location, distribution, vharacter of tumor and shoice of treatment, we are dependent upon the eystoseope. of the rystoscopes commonly used, we have three prominent types - the direct, corrected and uncorrected indimet instruments. From this, it is obrious that the exclusive use of a direct anainst an indirect may make for incomplete diarnosis. This is well exemplified in an experience that I had a fow years aro, wherein I employed an indirest instrument and true, found a tumos lyiner well to the right of the trigrone. The chatricter of the mass and its contour led mo to believe it malignant. This was confirmed by my having tallen a piece with a eystoseopic rongetur for sections. From its apparent isolation it was deemed wise to do a cystotomy, hus' down and resect with cautery knife. This plin followed, we encountered a very much larger growth in the dome of the bladder" which was well without the line of vision of the indires instrument. Hat I used the direct instrument, the chances for hasind missed the first and smaller tumor would have been rely great. Due to the fact that this latter tumor was so large and fiat, we thought resection unwise, At any rate, much of both was burned down by the electrie cautery. Iater, cystectomy was thought of, recommended, a:cepted and aceomplished. This was done and the ureters drawn out and anchored lateral to the recti muscles. In a few days the ureter's broke their moorings and returned to the bladder lair. they were localed, novocaine employed for anesthesia and ureters returned and more securely anchored. This having been done, No. 15 French eatheters were inserted and drainage established. The recovery was slow and tedious, hut to this date the patient has lived for over three and a half years, the most of which time he has been conducting his business satisfactorily to hinself and others.

I am by no means sure that this is the point of election for ureteral transplantation, hut if all patients do as well where the ureters are placed elsewhere, after explanation, the patients might have their choice of electing their points of drainage.

Dr. Brumsionl Leuis, St. Louis, Wo.-In the last ten or fifteen years in talking to students about hematuria I have insisted that the proper object of the doctor in the presence of hematuria was not to cure the hematuria; that he should at first have one object in view, which was to find out the source and cause of the bleeding.

With regard to tumors of the bladder, when we have decided that they are tumors-I think we can not make the diagnosis by the symptomatology, but by correct diagnosis with the cystoscope-the first thine is to decide the character of the tumor, as already pointed out by Dr. Ballenger in his excellent paper. The next point is in requad to the curability, even if malignant. I am convinced that carcinomas should be subjected to the more efficient treatments that have been brought out in the last few years. I have four cases in mind that were inoperable that gave very interesting results. One patient was a woman who had such an enornous tumor that one had no space for workinf with the eystoscope, and one could only see it large cauliflower growth of eareinoma. She was taking a grain and a half of morphin a day to alluy her sulfering, and from every standpoint the case was very unpromising. Instead of relying upon one method of treatment, I used radium, the deep intensive x-rays, and fulguration throurh the cystosione, Within ten months. inserad of beine in the excededingly bad condition which was present at the beginninge, she was: greatly inproved. Sha is now awily on an atatomohile trip; the tumor has distippeared except for an ulerating area, and she has wo far propressed that she and her hushand and every one is delighted. She has gained at least thirty pounds and is feeling well. In two other wases the tumols have entirely disappeared and the hiadiler walls are free. In the fourth case the only cridence of trouble is hematuria from the right hidney, lout the bladder is free. There a four cases of definite malignancy that have heen reared up or vastly improved, so we have that much encouragement to report from the use of these mothods.

Good eferets are obtained provided the gethemal profession brings the patient to us for the ireituonts before it is too late.

With reforence to the little detail of technic, the short cirat, I believe I)r. Caulk had a rery serious time once with a short cireuit. I have a rheostat that is wound with one coil inside the other, providing an induction eurrent so onk can not get a direct comnection through it. Since using that. I have harl no short cireuit.

IN. A. J. Crouch, Charlote, N. C.-I am not o: my feet to discuss this paper, but to ask our Chiaiman to discuss it and tell us about the use of radium in such cases. I think it a very important subject and radium a very importani factor in the treatment of these conditions. have seen some very exellent results obtainerl frem jts use in benign as well as malignant tumors of the bladder. I have just visited one of the great clinies in this country and find th $^{3}$ ac operating first and then use radium. I thisk DIs. Geraghty and loung apply radium befo:e oreration.

Dr. John T. Gerayhly, Baltimore, Ml.-Our experience with radium now dates over a period of four atd a haif years. We find that all benign, all malignant and possibly all of the reourrent papillomas will disappear unier radium. We bave found that in the cases where the tumor infiltrates the bladder our results so far have been negative. We have not yet cured any infiltrating tumor of the bladder. If the tumor is an infiltrating carcinoma it is our custom, if it is operable, to do a resection and not waste time in using radium on that tumor.

Tumors which are not infiltrating should not be operated upon. but treated with radium or ralium in combination with fulguration, and the results from this treatment are much superior to our operative results obtained in the past.

Dr. Lilllenge" (closing).-There is nothing I wish to add, except to thank those who have discussed the paper. 